\title{
Interrelationships Between Apoptosis and Fertility in Bull Sperm
}

\section{Sule DOGAN ${ }^{1) *}$, Melissa C. MASON ${ }^{1,2) *}$, Aruna GOVINDARAJU ${ }^{1)}$, Lauren BELSER ${ }^{1)}$, Abdullah KAYA ${ }^{3)}$, John STOKES ${ }^{4)}$, Dennis ROWE ${ }^{5)}$ and Erdogan MEMILI')}

\author{
1) Department of Animal and Dairy Sciences, Mississippi State University, Starkville, MS 39762, USA \\ 2) Alcorn State University, Lorman, MS 39096, USA \\ 3) Alta Genetics, Incorporated, Watertown, WI 53094, USA \\ 4) Department of Basic Sciences, Mississippi State University, Starkville, MS 39762, USA \\ ${ }^{5)}$ Mississippi Agricultural and Forestry Experiment Station, Mississippi State University, Starkville, MS 39762, USA
}

\begin{abstract}
Male fertility, the ability of sperm to fertilize and activate the egg and support early embryogenesis, is vital for mammalian reproduction. Despite producing adequate numbers of sperm with normal motility and morphology, some males suffer from low fertility whose molecular mechanisms are not known. The objective was to determine apoptosis in sperm from high and low fertility bulls and its relationship with male fertility. DNA damage, phosphatidylserine (PS) translocation, and expression of pro- and anti-apoptotic proteins (BAX and BCL-2) in the sperm were determined using TUNEL, Annexin $\mathrm{V}$, and immunoblotting approaches, respectively. Amounts of apoptotic spermatozoa were $2.86( \pm 1.31)$ and $3.00( \pm 0.96)$ in high and low fertility bulls, respectively $(\mathrm{P}=0.548)$, and were not correlated with fertility. There was a negative correlation between early necrotic spermatozoa and viable spermatozoa $(\mathrm{r}=-0.99, \mathrm{P}<0.0001)$. Fertility scores were correlated with live spermatozoa detected by eosin-nigrosin test and necrotic spermatozoa determined via flow cytometry $(\mathrm{r}=-0.49, \mathrm{P}<0.006$ and $\mathrm{r}=-0.266, \mathrm{P}<0.0113$, respectively). BAX level was higher in low fertile group than high fertile group; however, this difference was not statistically significant due to the variations of bull samples (Bull 1-3 vs. Bull 4-5) in low fertile group $(\mathrm{P}<0.283)$. BCL-2 was not detectable in any of the sperm samples. The results shed light onto molecular and cellular underpinnings of male fertility.
\end{abstract}

Key words: Apoptosis, DNA damage, Male infertility, Sperm

(J. Reprod. Dev. 59: 18-26, 2013)

$\mathbf{T}$ he quality of paternal DNA transmitted through sperm is an important factor for maintaining the reproductive potential of males, fertilization, embryonic development, and beyond [1, 2]. Apoptosis or programmed cell death is a major factor proposed to cause DNA damage in spermatozoa [3, 4] before and after spermatogenesis. Apoptosis naturally removes unnecessary or damaged cells and contributes to the maintenance of homeostasis in tissues; [3, 4] indeed, abnormal apoptotic processes might result in abnormal sperm development [5]. Stages of induction, execution, and degradation [6] as well as signaling pathways of intrinsic and extrinsic origin are involved in apoptosis Fig 1. Signals for the extrinsic pathway are activated by receptors from the tumor necrosis factor family (TNF's), and signals for the intrinsic pathway are triggered by factors such as oxidative stress and nuclear or mitochondrial DNA damage [5, 7].

Apoptosis is one of the well-known cell death mechanisms with necrosis and it is regulated by several genes and molecules that all play a large role in the initiation of apoptosis, such as BAX, BAK, PUMA, p53, c-Myc and Bcl-2 (the B-cell lymphoma/leukemia 2) family members that consist of pro- and anti-apoptotic factors (See

Received: April 19, 2012

Accepted: August 27, 2012

Published online in J-STAGE: September 14, 2012

(C)2013 by the Society for Reproduction and Development

Correspondence: E Memili (e-mail: em149@ads.msstate.edu)

* S Dogan and MC Mason contributed equally to this work.
[8] for further information) which also trigger other caspases [6, $7,9,10]$. Activation of BAX/BAK1 proteins trigger the release of cytochrome $\mathrm{c}$ and other apoptogenic factors from the mitochondria leading to apoptosome formation, which then activates caspase- 9 with caspase- 3 and 7 [7]. In the course of apoptosis, a translocation of PS from the cell membrane occurs on surface of the apoptotic cells recruiting the neighboring macrophages for phagocytization, which is the main difference from necrosis $[9,11]$. Sperm DNA damage induced by apoptosis has been demonstrated in different mammals by several research groups: human, [4, 5, 12-14]; bovine $[6,9,11,15]$; and murine $[16,17]$. The balance between germ cells and sertoli cells in the testes during spermatogenesis is maintained by apoptosis and an imbalance in this process was shown to cause infertility in males [7].

Mechanisms of male infertility have not been researched as extensively as female infertility and have only become of major interest within the last two decades. There is still a significant gap in the knowledge base of these mechanisms and their relationship to sperm DNA damage and apoptosis. It has been found that increased levels of apoptotic spermatozoa have a direct influence or impact on poor bull fertility by decreasing sperm viability $[6,9,11]$. Conventional semen analysis has proven to be a poor predictor of reproductive outcomes and seems to be testing subjective rather than quantitative evaluations of male fertility.

Studies have shown that sperm DNA damage is negatively associated with fertilization rate, implantation, successful pregnancy [5, 


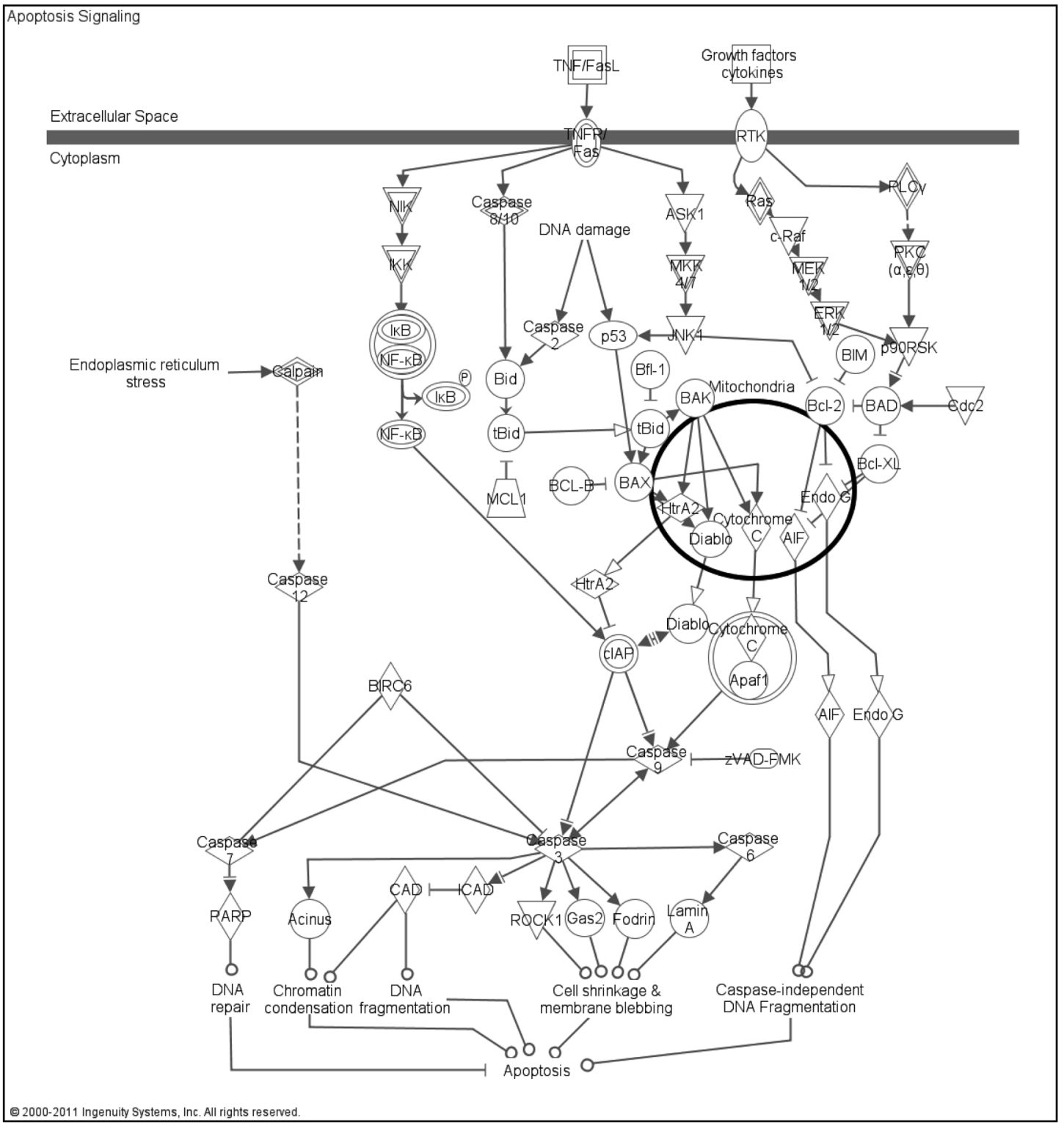

Fig. 1. Apoptosis signaling pathway. The intrinsic and extrinsic pathways with the molecules that are involved in these pathways are represented. Molecular mechanisms of the BAX and BCL-2 including their interaction with the mitochondria can be also seen. The picture was generated by IPA Pathway Analysis software.

$18,19]$, higher occurrences of miscarriage [7], and is also related to field fertility of bull semen [20]. However, contrary results have been reported by others [21-26]. Since this relationship is still unsettled, details of mechanisms causing DNA damage as well as the specific effects of damaged DNA on fertility largely remains unclear. Despite the importance of male infertility, there are no reliable molecular biomarkers to determine semen quality and bull fertility. The purpose of this study was to determine apoptosis in sperm from bulls with varying fertility and to determine to what extent DNA integrity is linked to bull fertility. In addition, we investigated if apoptotic proteins could be the best biological marker(s) that could estimate the fertility score for males. Is determination of apoptosis really necessary to predict the sperm DNA integrity and male fertility? Instead of apoptosis determination, what kind of test could be cost-effective? This study focused on the investigation of the apoptosis paradox concerning why different bulls are able to provide similar numbers of sperm cells with normal morphology, motility and viability, and yet have differences in fertility.

\section{Materials and Methods}

All chemicals and reagents are stated or are otherwise supplied from Sigma (MO, USA). The experimental design of this study is presented in Fig. 2. 


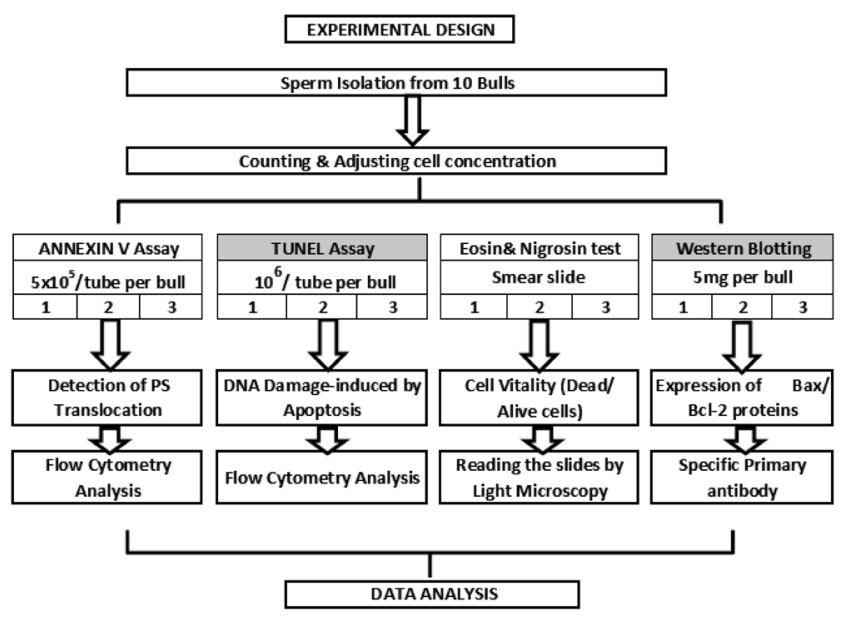

Fig. 2. Experimental design. Overall, sperm samples from 10 bulls were used for each experiment. First spermatozoa isolated and separated into four aliquots to perform each assay followed by counting. Total of nine reads per bull with three technical replicates in three different times was performed for TUNEL and ANNEXIN V experiments. Two technical replicates within three different times approach meaning that six reads per bull was accomplished for eosin \& nigrosin test, and a hundred of spermatozoa were counted per slides. Western blotting with three replicates was done by using $5 \mu \mathrm{g}$ of protein per bull for the accuracy, and the intensity of protein bands in the pictures were determined via software (Suppl Fig. 2: online only).

\section{Determination of bull fertility}

In this study, we used sperm from bulls that produce abundant amounts of sperm with normal motility and morphology. Thus, this study addresses so called "uncompensatory fertility" where it is thought that molecular defects in the sperm cause sub-par fertility [27]. In the Alta Advantage Program (Alta Genetics, Watertown, WI, USA), fertility of bulls are predicted quarterly using updated data from partnering herds as described in [28]. The list of the bulls and fertility phenotypes used in this study is shown in Table 1 . The environmental and herd management factors that influence the fertility performance of the sires are adjusted using threshold models which are similar to previously published models by Zwald et al. [29, 30]. Estimation of parameters and fertility prediction were obtained using Probit F90 software that was developed by Chang [31]. The outcome of each breeding event and the environmental factors, such as the effects of herd-year-month, parity, cow, days in milk, and sire proven status are adjusted. Afterwards, the fertility of each sire was expressed as the percent deviation of its conception rate from the average conception of all bulls in the database with at least 300 breeding outcomes. For this study, we used the standard deviation (SD) of the population as the criterion to classify bulls as high and low fertility. Bulls having 2 SD above the average were considered as high-fertility, and those that are 2 SD below the average were considered as low-fertility. Thus, the fertility differences between high and low fertility groups were $4 \mathrm{SD}$ which can be considered extreme outliers for the given population. Additionally, bulls were required to have a minimum of 500 breeding records to be qualified for higher reliability.
Table 1. Fertility differences among the bulls

\begin{tabular}{ccc}
\hline Bull & Number of breeding & $\begin{array}{c}\text { \% Fertility deviation } \\
\text { from average }\end{array}$ \\
\hline Low fertile bulls & & \\
1 & 1134 & -14.7 \\
2 & 769 & -9.1 \\
3 & 1671 & -8.1 \\
4 & 888 & -7.2 \\
5 & 819 & -5.6 \\
Mean & $1056.2 \pm 371.2$ & $-9.94 \pm 3.6$ \\
\hline
\end{tabular}

High fertile bulls

$\begin{array}{ccc}6 & 560 & 5 \\ 7 & 594 & 5 \\ 8 & 1222 & 5.1 \\ 9 & 1138 & 5.6 \\ 10 & 895 & 6.2 \\ \text { Mean } & 881.8 \pm 303.3 & 6.14 \pm 1.1\end{array}$

List of bulls and their fertility scores according to Alta Genetics data base including bulls' breeding numbers. Bulls are listed according to their fertility scores where Bulls 1-5 and Bulls 6-10 represent low and high fertility groups, respectively.

\section{Isolation of sperm cells}

Cryopreserved semen samples of ten bulls with varying fertility were provided by Alta Genetics. The samples were thawed and for each bull, the total spermatozoa collected were purified by Percoll gradient centrifugation according to [28] with minor changes. Briefly, the spermatozoa were isolated by using $45 \%$ Percoll prepared with 90\% Percoll and phosphate-buffered solution (PBS; Gibco, Invitrogen, Carlsbad, CA, USA) at $700 \mathrm{~g}$ for $15 \mathrm{~min}$ to only remove the cryopreservation extender, sperm pellets were then washed with PBS at $700 \mathrm{~g}$ for $10 \mathrm{~min}$. Using this method, sperm population was not selected based on motility or morphology. This is consistent with previous studies where this approach does not allow sperm selection to take place based on their viability, motility or cell integrity [32]. Cell numbers were determined using a hemocytometer and cell concentration in warmed PBS was adjusted to $5 \times 10^{5} / \mathrm{ml}$ for Annexin V assay (Annexin-V-FLUOS Staining Kit, Roche Applied Science, Indianapolis, IN, USA) and $1 \times 10^{6} / \mathrm{ml}$ for TUNEL assay (In Situ Cell Death Kit, Roche Diagnostics, Indianapolis, IN, USA). All centrifugations were performed at room temperature and spermatozoa were stored in an incubator at $37 \mathrm{C}$ prior to Annexin $\mathrm{V}$ and TUNEL assays to avoid the oxidative shock and to maintain the accuracy of the results.

\section{TUNEL assay}

Following the sperm isolation, the sperm pellets were washed twice in PBS with $0.1 \%$ Bovine Serum Albumin (BSA) and suspended in $100 \mu \mathrm{l}$ of $\mathrm{PBS} / 0.1 \% \mathrm{BSA}$. The pellets were then fixed in $100 \mu \mathrm{l}$ of $4 \%$ paraformaldehyde at room temperature for $60 \mathrm{~min}$, resuspended in $100 \mu \mathrm{l}$ of PBS and then permeabilized in $100 \mu \mathrm{l}$ of $0.1 \%$ Triton $\mathrm{X}-100$ in $0.1 \%$ sodium citrate in PBS on ice for $2 \mathrm{~min}$. While the ten individual pellets were being fixed and permeabilized, the TUNEL reaction mixture was prepared by removing $100 \mu \mathrm{l}$ of label 
solution for two negative controls and adding the total volume (50 $\mu 1)$ of enzyme solution to the remaining $450 \mu \mathrm{l}$ label solution to obtain $500 \mu 1$ TUNEL reaction mixtures. The negative control was incubated, fixed and permeabilized in $50 \mu 1$ of label solution without the TdT enzyme, while the positive control was incubated, fixed and permeabilized with DNase 1 (100 IU, Invitrogen) at $25 \mathrm{C}$ for $10 \mathrm{~min}$. Next, the pellets were washed twice with $200 \mu$ of PBS/0.1\% BSA and then resuspended in $50 \mu 1$ TUNEL reaction mixture; including the positive control. Once the TUNEL reaction mixture had been added, the samples were incubated at $37 \mathrm{C}$ in the dark for $60 \mathrm{~min}$. The samples were then washed with $200 \mu 1$ of PBS $/ 0.1 \%$ BSA, placed into a transparent tube with a final volume of $400 \mu 1$ in PBS and were immediately analyzed by flow cytometry (FACSCalibur, BD Biosciences, San Jose, CA, USA). The TUNEL assay was observed using fluorescence microscopy (Axiovert $200 \mathrm{M}$ Inverted Research microscope, Zeiss, Göttingen, Germany) prior to flow cytometry to determine to what extent the assay has worked. The data were then expressed in a flow-cytometric plot. All experiments were repeated three times by using three experimental replicates $(\mathrm{n}=90 ; 9$ different reads per bull).

\section{Annexin $V$ assay}

For the Annexin V assay, Annexin-V-FLUOS Staining Kit (Roche Applied Science) was used according to the manufacturer's recommendations. Briefly, Annexin-V-FLOUS labeling solution was prepared by combining $20 \mu \mathrm{l}$ of AnnexinV-Flous labeling reagent and $20 \mu \mathrm{l}$ of propidium iodide (PI). Next, the isolated sperm samples were re-suspended in $100 \mu \mathrm{l}$ of AnnexinV-Flous labeling solution at $37 \mathrm{C}$. This mixture was then incubated at room temperature in the dark for $10 \mathrm{~min}$. Following incubation, $400 \mu \mathrm{l}$ of incubation solution was added to each sample and analyzed using the flow cytometer. A flow-cytometric plot of frozen-thawed sperm after Annexin V assay is represented in Suppl Fig. 1 (available at www.jstage.jst. go.jp/browse/jrd). Annexin-V/PI assay can distinguish four different subpopulations of cells, representing in the related fig. Among spermatozoa population, late necrotic spermatozoa were stained with PI, but not with Annexin V whereas early necrotic spermatozoa were labeled with both Annexin V and PI. Viable spermatozoa were stained by neither Annexin V nor PI, while apoptotic spermatozoa were labeled only by Annexin V, but not by PI. In order to confirm sperm cell viability, $10 \mu \mathrm{l}$ of sperm suspension was mixed with $10 \mu \mathrm{l}$ of eosin-nigrosin staining solution to prepare a smear slide according to [33]. Eosin stains the postacrosomal region of spermatozoon while nigrosin penetrates into the acrosome. They are usually used together to better evaluate spermatozoa via light microscopy [34]. Afterwards, a total of 100 sperm cells per slide were counted under light microscope. All experiments were repeated three times by using three experimental replicates.

\section{Isolation of spermatozoal proteins}

Sperm cells were isolated according to the protocol listed above and washed with PBS containing protease inhibitor cocktail (Roche Applied Science) to avoid protein degradation, and then stored at $-80 \mathrm{C}$ until protein isolation. Spermatozoal proteins were extracted using SDS sample buffer containing $66 \mathrm{mM}$ Tris- $\mathrm{HCl}$ (pH-6.8), 26\% glycerol, and $2 \%$ SDS. Next, $5 \mu 1$ of $\beta$-Mercaptoethanol was added fresh to $95 \mu 1$ of SDS sample buffer. The sperm pellets were then re-suspended in the above mixture, vortexed for $30 \mathrm{sec}$ followed by boiling the samples for $10 \mathrm{~min}$. The samples were then cooled on ice for two min prior to centrifugation at $4 \mathrm{C}$ and $700 \mathrm{~g}$ for 10 min. The supernatant containing the proteins were then quantified using microBCA protein assay (Thermo Scientific, Rockford, IL, USA.) method according to the manufacturer's recommendations.

\section{Immunodetection of apoptotic proteins}

Equal amounts ( $5 \mathrm{mg} /$ well) of the isolated proteins were loaded from Bull 1 to 10 based on their fertility scores and separated in $10 \%$ SDS-polyacrylamide gels [35], and then they were transferred onto polyvinylidene fluoride (PVDF) membranes by the semi-dry transfer method using HEP-1 Semidry Electroblotting (Thermo Scientific). The membrane was then blocked with 1xTris buffered saline with $1 \%$ casein for $60 \mathrm{~min}$ (Bio-Rad, Hercules, CA, USA) at room temperature and incubated with primary antibodies, BAX (N-20) and BCL-2 (N-19) (sc-493 and sc-492 from Santa Cruz, CA, USA) at $4 \mathrm{C}$ overnight with the dilutions of 1:1000 and 1:250, respectively. Beta-tubulin (N-20) (sc-9935 from Santa Cruz, CA, USA) was co-used as loading control for each primary antibody with the dilution of 1:500. The next day, the membrane was washed three times at room temperature for 15 min each time with washing buffer containing $1 \%$ Tween 20 , followed by incubation with secondary antibodies conjugated to horseradish peroxidase (Donkey anti-rabbit IgG-HRP, sc-2313 for Bcl2 and BAX and donkey anti-goat IgG-HRP, sc-2020 for $\beta$-Tubulin from Santa Cruz) at room temperature for 60 min. Following washing, chemiluminescent substrate (WBKLS0500, Millipore, Billerica, MA, USA) was added to the membrane to detect the signals. We used a protein marker (EZRun Protein Marker, Fisher scientific, Pittsburgh, PA, USA) to estimate the size of the proteins of interest using specific primary antibodies with known molecular weight. Besides, for both antibodies, we tested their specificity and reactivity prior to the experiments. We used testis tissue as positive control and incubated membranes without primary antibodies as negative control for each protein. Following immunoblotting, the intensities of the bands were quantified using Image Lab software (Bio-Rad). Suppl Fig. 2 (available at www.jstage.jst.go.jp/browse/jrd) shows the intensities of the protein bands detected via western blotting for their distribution in each group prior to data analysis. Besides, testing of the primary antibody non-specificity was performed using testis and sperm samples with only secondary antibody incubation (donkey anti-goat IgG-HRP) prior to real experiments (see suppl Fig. 3 available at www.jstage.jst.go.jp/browse/jrd).

\section{Statistical analysis}

All percentage data was first verified to be normally distributed, and then analyzed with SAS Version 9.2 for Windows (SAS Institute, Cary, NC, USA). Data were obtained from three different trials with three technical replicates for apoptosis and TUNEL experiments, with two technical replicates for eosin-nigrosin test and without technical replicates for western blotting. In other words, nine, six and three measurements per bull were used for data analysis from the apoptosis and TUNEL experiments, eosin-nigrosin test and western blotting, respectively. Total numbers of measurements were classified into two groups high and low fertility bulls, and then analyzed using 

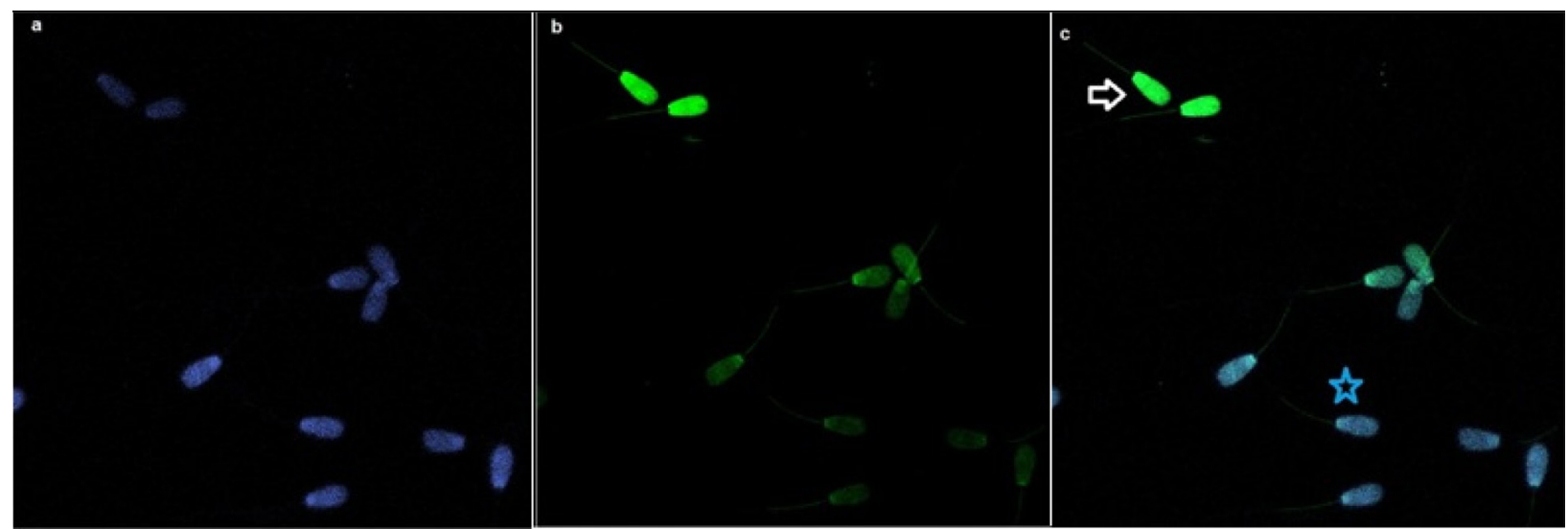

Fig. 3. Bull sperms with TUNEL assay by fluorescence microscopy. a: DAPI stained sperm samples with the objective\#1. b: TUNEL assay with the objective\#2. c: Overlap of two pictures; white arrow indicates DNA fragmented sperm cells (apoptotic) which stained as green whereas blue star shows DNA integrity of the sperm (non-apoptotic) containing blue color.

ANOVA test including mean values $( \pm$ STD). Since we designed the experiments based on the $3 \times 3,3 \times 2$ and 3 replicates per bull for from the apoptosis and TUNEL experiments, eosin-nigrosin test and western blotting, respectively, we could be able to compute the data using ANOVA test. Overall relation among the data was performed using Pearson correlation analysis determining any significant $(\alpha \leq .05)$ linear associations between fertility, necrotic spermatozoa, early necrotic spermatozoa, viable spermatozoa, apoptotic spermatozoa, live spermatozoa, dead spermatozoa, spermatozoa with DNA fragmentation, and BAX regardless of any grouping. A multiple regression analysis was used to determine which combination of measured variables might best predict the level of fertility.

\section{Results}

All parameters that were used for analysis are listed in Table 2 and Pearson correlation coefficients are shown in Table 3.

\section{Fertility differences among the bulls}

The fertility data were determined as the deviation from average fertility values of around 1,000 bulls. Fertility results of five high and five low-fertility bulls are summarized in Table 1 . The average fertility of high and low fertility groups were $6.14 \pm 1.1$ and $-9.94 \pm$ $3.6 \%$ of the average $($ Zero $=0)$, respectively. This allowed us a unique group of samples which had $16.08 \%$ fertility difference between high and low fertility group. The average breeding for the high and low fertility groups were $881.8 \pm 303.3$ and $1056.2 \pm 371.2$, respectively $($ Mean \pm SD) (Table 1).

\section{Extent of DNA damage in sperm}

Spermatozoa with DNA fragmentation were detected using flow cytometry. The percentage of sperm with TUNEL positive (DNA damaged) in high and low fertility bulls was $3.51( \pm 2.23)$ and 3.61 $( \pm 2.20)$, respectively; there was no significant difference between the two groups $(\mathrm{P}=0.826)$ (Table 2). Likewise from apoptosis results, there was no detection of any correlation between DNA fragmentation and fertility score. There was also no significant correlation between
Table 2. Comparison of two groups (High vs. low fertility bulls)

\begin{tabular}{lccc}
\hline \multicolumn{1}{c}{ Parameters } & $\begin{array}{c}\text { High } \\
(\text { Mean } \pm \mathrm{SD})\end{array}$ & $\begin{array}{c}\text { Low } \\
(\text { Mean } \pm \mathrm{SD})\end{array}$ & P-value \\
\hline Necrotic spermatozoa & $3.48 \pm 1.59$ & $4.13 \pm 1.86$ & 0.079 \\
Early necrotic spermatozoa & $31.04 \pm 9.27$ & $32.13 \pm 9.26$ & 0.579 \\
Viable spermatozoa & $62.62 \pm 9.1$ & $60.72 \pm 8.51$ & 0.311 \\
Apoptotic spermatozoa & $2.86 \pm 1.31$ & $3.00 \pm 0.96$ & 0.548 \\
DNA fragmented spermatozoa & $3.51 \pm 2.23$ & $3.61 \pm 2.20$ & 0.826 \\
Alive spermatozoa & $52.60 \pm 7.06$ & $59.27 \pm 8.61$ & $0.028^{*}$ \\
Western blot & $2.47 \pm 0.72$ & $3.36 \pm 3.23$ & 0.283 \\
\hline
\end{tabular}

All parameters that were used for the analysis are the percentage of flow cytometric Annexin V assay results as necrotic, early necrotic, viable, apoptotic spermatozoa, and the ratio of DNA fragmented spermatozoa determined by TUNEL, the percentage of alive spermatozoa according to eosin-nigrosin test, the expression $(\mu \mathrm{g})$ of BAX determined via western blotting. All responses are compared between two groups and listed as mean and standard division including P-values.

TUNEL assay and viable spermatozoa, necrotic, early necrotic and apoptotic spermatozoa detected by Annexin V (Table 3). The TUNEL assay was established by fluorescent microscopy prior to flow cytometry and spermatozoa with and without DNA fragmentation are shown (Fig. 3). As a nuclear stain, DAPI was performed and DNA fragmented spermatozoa were stained green compared to those that were stained blue (DAPI), which represented spermatozoa with non-fragmented DNA.

\section{Detection of apoptosis via Annexin $V$}

The flow cytometric plots of spermatozoa from two bulls with different fertility are shown in Fig. 4; bull K_1.002 (Bull 1) is low fertility and bull E 3.031 (Bull 10) is high fertility. The percentage of apoptotic spermatozoa in high and low fertility bulls was $2.86( \pm$ $1.31)$ and $3.00( \pm 0.96)$, respectively; there is no significant difference between groups $(\mathrm{P}=0.548)$. In addition to apoptotic spermatozoa, the percentages of necrotic, early necrotic and viable spermatozoa in high and low fertility bulls were $3.48( \pm 1.59), 31.04( \pm 9.27)$, 
Table 3. Pearson correlation coefficients with $\mathrm{P}$ values for significant

\begin{tabular}{|c|c|c|c|c|c|c|c|}
\hline Responses & $\begin{array}{c}\text { Necrotic sperm } \\
(\%)\end{array}$ & $\begin{array}{l}\text { Early necrotic } \\
\text { sperm (\%) }\end{array}$ & $\begin{array}{c}\text { Viable sperm } \\
(\%)\end{array}$ & $\begin{array}{c}\text { Apoptotic sperm } \\
(\%)\end{array}$ & $\begin{array}{c}\text { DNA damage } \\
(\%)\end{array}$ & $\begin{array}{l}\text { Alive sperm } \\
(\%)\end{array}$ & $\begin{array}{c}\text { BAX } \\
(\mu \mathrm{g})\end{array}$ \\
\hline Fertility score & $\begin{array}{c}-0.266^{*} \\
P=0.0113\end{array}$ & -0.01 & 0.072 & -0.063 & -0.017 & $\begin{array}{c}-0.49^{*} \\
(\mathrm{P}=0.0056)\end{array}$ & $\begin{array}{c}-0.301 \\
(\mathrm{P}=0.1106)\end{array}$ \\
\hline Necrotic spermatozoa (\%) & & $\begin{array}{c}-0.506^{*} \\
(\mathrm{P}<.0001)\end{array}$ & $\begin{array}{c}0.420^{*} \\
(\mathrm{P}<.0001)\end{array}$ & $\begin{array}{c}-0.688^{*} \\
(\mathrm{P}<.0001)\end{array}$ & 0.025 & $\begin{array}{c}0.377 * \\
(\mathrm{P}=0.04)\end{array}$ & 0.223 \\
\hline Early necrotic spermatozoa (\%) & - & & $\begin{array}{c}-0.991^{*} \\
(\mathrm{P}<0.0001)\end{array}$ & $\begin{array}{c}0.358^{*} \\
(\mathrm{P}=0.0006)\end{array}$ & -0.039 & $\begin{array}{c}-0.435^{*} \\
(\mathrm{P}=0.016)\end{array}$ & 0.05 \\
\hline Viable spermatozoa (\%) & - & - & & $\begin{array}{c}-0.367^{*} \\
(\mathrm{P}=0.0004)\end{array}$ & 0.052 & $\begin{array}{c}0.386^{*} \\
(\mathrm{P}=0.035)\end{array}$ & -0.094 \\
\hline Apoptotic spermatozoa (\%) & - & - & - & & -0.126 & -0.084 & -0.0832 \\
\hline DNA fragmentation (\%) & - & - & - & - & & -0.144 & -0.219 \\
\hline Alive spermatozoa (\%) & - & - & - & - & - & & 0.23 \\
\hline
\end{tabular}

The correlation of the variables necrotic, early necrotic, viable, apoptotic spermatozoa, DNA fragmented spermatozoa, alive spermatozoa, BAX and bulls' fertility scores.

$62.62( \pm 9.1)$ and $4.13( \pm 1.86), 32.13( \pm 9.26), 60.72( \pm 8.51)$, respectively. Although the percentages of these variables in high fertility bulls were lower than those in low fertility counterparts, there was no significant difference of necrotic, early necrotic and viable spermatozoa between the three groups $(\mathrm{P}=0.079,0.579$ and 0.311 , respectively) (Table 2). There was a negative correlation between early necrotic spermatozoa and viable spermatozoa detected via flow cytometry ( $\mathrm{r}=-0.991, \mathrm{P}<0.0001)$. In addition, apoptotic spermatozoa showed a positive correlation with early necrotic spermatozoa $(\mathrm{r}=0.358, \mathrm{P}<0.01)$, whereas a negative correlation with necrotic spermatozoa and viable cells $(\mathrm{r}=-0.688, \mathrm{P}<0.0001 ; \mathrm{r}=-0.367$,
$\mathrm{P}<0.05$, respectively) was seen (Table 3 ). Eosin-nigrosin test was done to confirm flow cytometric data and its results were indicated as alive sperm in the data (Tables 2 and 3). Two microscopic slides of eosin-nigrosin stain from two different bulls are shown in Fig. 5; live spermatozoa were not stained while dead spermatozoa were labeled with the stain. A live cell population in high and low fertility bulls was $59.27( \pm 8.61)$ and $52.60( \pm 7.06)$ and this difference was significant $(\mathrm{P}<0.01)$ in Table 3 . Besides, it showed a positive correlation with viable cells and a negative correlation with early necrotic spermatozoa detected by flow cytometry $(\mathrm{r}=0.386, \mathrm{P}<0.04$; $\mathrm{r}=-0.435, \mathrm{P}<0.02$, respectively). There was a negative correlation
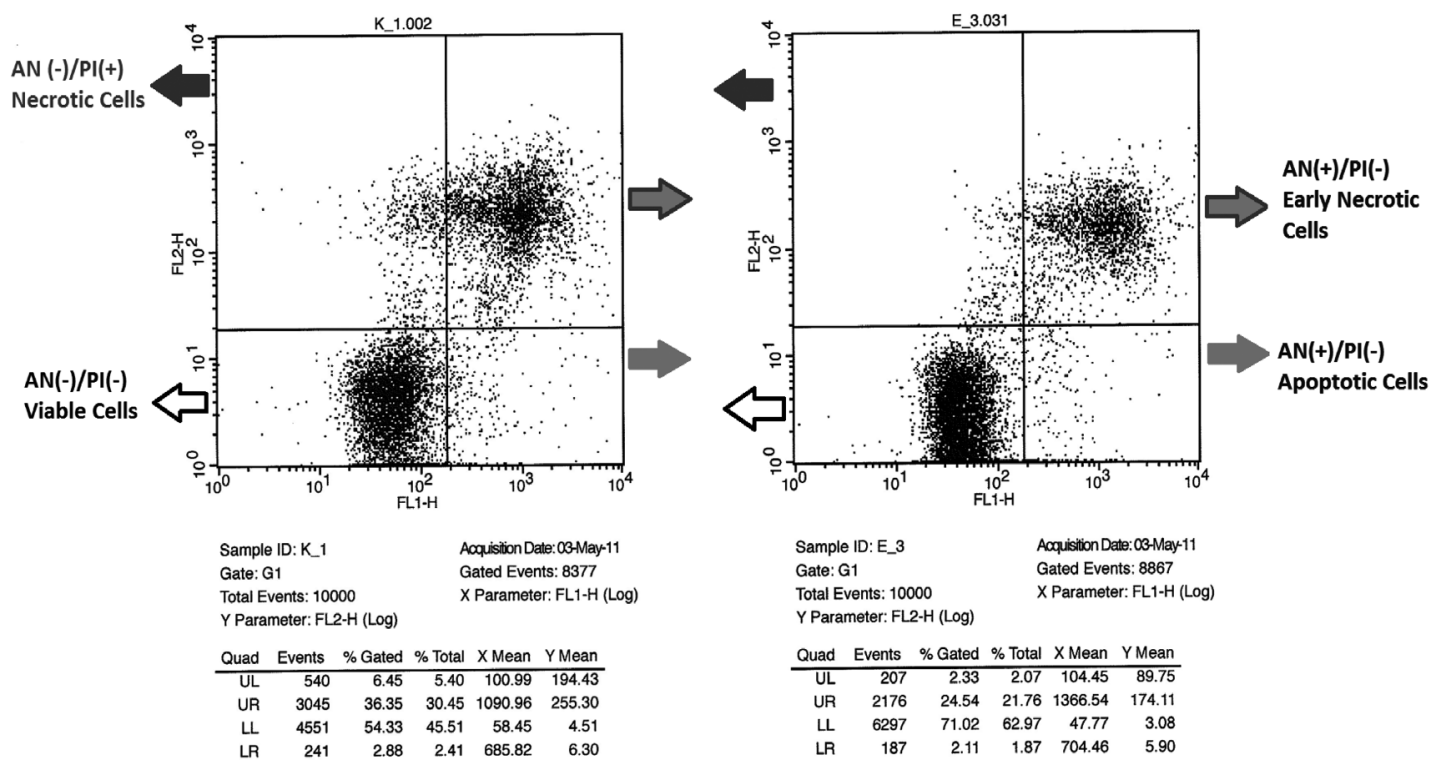

Fig. 4. Sperm apoptotic cell population of two bulls with varying fertility by flow cytometry. K 1.002 (Bull 1) is low fertility bull and E_3.031 (Bull 10) is high fertility bull. The percentage of necrotic, early necrotic, viable and apoptotic spermatozoa gated can be seen in both in the figures and in the tables as UL (upper-left), UR (upper-right), LL (lowerleft), LR (lower-right), respectively. 

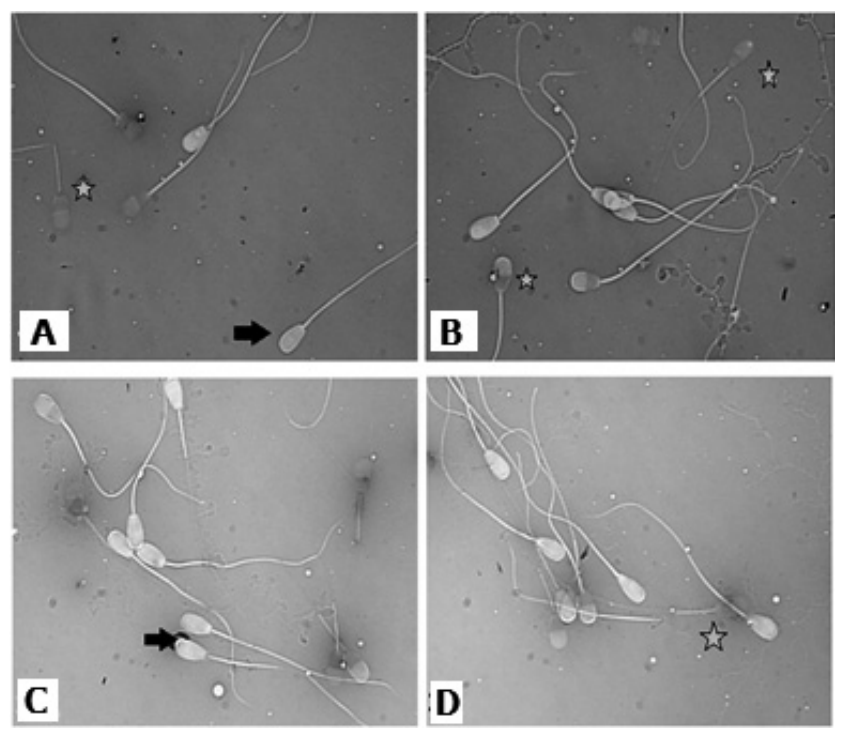

Fig. 5. Eosin/nigrosin staining. Two microscopic slides of eosin-nigrosin stain from two different bulls are shown; live spermatozoa were not stained showing with black arrow while dead spermatozoa were labeled with the stain marking with the star.

between live spermatozoa detected by eosin-nigrosin test and fertility score, and this was statistically significant $(\mathrm{r}=-0.49, \mathrm{P}<0.05)$. No correlation between apoptosis and DNA fragmentation was shown.

\section{Detection of apoptotic proteins via immunoblotting}

The expression of BAX (pro-apoptotic), but not of BCL-2 protein (anti-apoptotic) was determined using WB, and the signal intensities from the expressed proteins among bulls were determined by Image Lab software (Bio-Rad). The size of BAX, Bcl 2 and $\beta$-Tubulin bands appeared to be around 23-kDa, 26-kDa and 55-kDa based on the protein marker. The expressions of BAX among bulls in high and low fertility bulls were $2.47( \pm 0.72)$ and $3.36( \pm 3.23)$, respectively. Although BAX was abundantly expressed in low fertility bulls compare to their high fertility counterparts, this relation was not significant $(\mathrm{P}=0.283$ ) (Table 2$)$. It was shown here that $\mathrm{BAX}$ was negatively correlated with fertility, but the results were not significant $(\mathrm{r}=-0.301, \mathrm{P}<0.12)$. The distribution of western blotting data among the groups high $v s$. low fertility can be seen in the Suppl Fig. 2 (online only). The intensities of the protein bands detected via western blotting are analyzed for their distribution in each group. Any correlation between protein expression and other parameters were determined. The expressions of BAX, BCL-2 and $\beta$-Tubulin among the bulls were shown in Fig. 6A. Testis sample from a bull with unknown fertility for each antibody was previously tested as a positive control to confirm the specificity of both antibodies, which was represented in Fig. 6B. The negative control of western blotting experiments for both antibodies (BAX and $\mathrm{Bcl} 2)$ where the only secondary antibodies were used is represented in the Suppl Fig. 3 (online only).

A stepwise multiple regression analysis with fertility as a dependent variable and the seven other variables as predictive independent variables found a highly significant regression using two predictor variables (necrotic spermatozoa detected by flow cytometry, alive spermatozoa determined via eosin-nigrosin stain).

\section{Discussion}

The significance of sperm DNA damage in semen is still debated as it may or may not be correlated with male fertility [7]. In this study, we used a bovine model to identify molecular markers and mechanisms regulating male fertility because there is a wealth of reliable information on bull fertility phenotypes derived from thousands of breedings and that significant similarities exist between reproductive physiologies and genomes of bovine and human. Since we obtained semen straws from the company with their reliable fertility scores based on not only the semen quality of these bulls, but also their breeding scores to calculate their fertility scores, the bull's fertility scores were accurate and in normal range, which were confirmed by a previous study [27].

In the course of apoptosis, BCL-2 anti-apoptotic and BAX proapoptotic proteins provide a signaling pathway that helps maintain the balance in a cell. The relative levels of these two groups of proteins are essential for whether the cell survives or undergoes apoptosis [36]. During spermatogenesis, BAX-mediated apoptosis serves as a checkpoint for maintaining the number and quality of spermatozoa. Also, it was demonstrated that BAX-deficient mice were sterile because of disordered maturation reflected by the absence of mature spermatocytes and the presence of pre-meiotic cells with
A

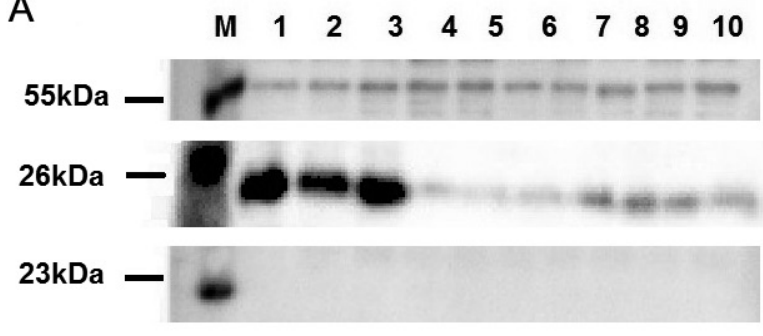

B

Tubulin

Bax

$\mathrm{Bcl} 2$
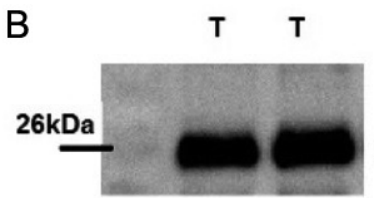

BAX

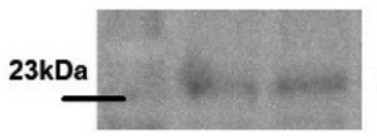

Fig. 6. BAX, BCL-2 and beta tubulin proteins. A: The expression of BCL-2 (anti-apoptotic), BAX (pro-apoptotic) and $\beta$-Tubulin proteins among the bulls. B: The expression of BCL-2 and BAX proteins using the same testis sample as positive control. M: Marker, T: Testis. Ten bulls were presented with their numbers from low fertility to the high fertility bulls 1 to 10 , respectively. 
an atypical distribution of decondensed chromatin [37]. A similar study by [6] also showed the expression of Bax, but not Bcl-2 in cryopreserved bovine spermatozoa. As was shown here, Bax expression was present in bull sperm while the $B c l-2$ was not detected [6]. For the $\mathrm{Bcl} 2$ western blotting, we used the same antibody used against Bcl2 in monkey testis by Zhang et al. [38], and in human testis [39]. We also confirmed the $\mathrm{Bcl} 2$ expression in bull testis as a positive control; therefore, we ensured that this antibody was specific enough to detect Bcl2 in bull spermatozoa. Furthermore, no cross-reaction was detected. In our study, results showed that BAX expression is not statistically different between high and low fertility groups and there is no significant correlation between male fertility and Bax expression. However, BAX expression was more abundant in bulls 1-3 that belong to the low fertility group compared to bull 4 and 5 in the same group and also bulls in the high fertility group. We showed the distribution of BAX among bulls in the supplementary file Fig. 2 in which the variations of BAX can be seen. One reason of these variations might be the differences in response to the cryo-damage within individuals during cryopreservation.

In addition to apoptotic proteins, DNA damage and PS translocation were determined using proper assays in our study. These assays were specific enough to evaluate apoptosis and to distinguish it from necrosis in frozen bull spermatozoa based on the literature [9, 18]. According to Chaveiro et al., spermatozoa undergo apoptosis during the incubation time followed by swim-up; thus, the viable cell population in that study is lower than what was observed in our study [15]. The correlation of fertility with DNA damage detected by TUNEL and PS translocation identified by Annexin V was significant in fresh bull sperm, but not in frozen samples, which was also supported by others [9]. In contrast to a study conducted by Henkel et al., our results did not show any correlation between fertility and PS translocation [18]. According to another study, 1.2\% $( \pm 0.7)$ of spermatozoa derived from two fertile bulls were TUNEL labeled concluding that bull sperm were resistant to the induction of caspase-mediated apoptosis following ejaculation [40], which was supported by our study. It was revealed that eosin-nigrosin stain was able to detect sperm vitality in bulls, and after thawing less than $50 \%$ of spermatozoa could survive [33]. Spermatozoa might be damaged by "cryo-shock" or "cold shock" containing possible damages to plasma, outer acrosomal membrane, acrosome and nucleus during cryopreservation. However, in regards to our own project, all of our samples were cryopreserved so that each sample was treated the same. Due to the cryopreservation of all of our samples our results are still objective because there was no mixture or comparison between cryopreserved and fresh samples. A future study for our lab could be to compare fresh vs. cryopreserved sperm samples for apoptosis, however, our current study focused on the comparison of apoptosis in sperm from high vs. low fertility bulls.

Unlike our results, DNA fragmentation in sperm was significantly associated with fertility while evaluating the sperm quality in relation to fertility after A.I. [20]. Additionally, Simon et al. concluded in their study that there was a significant negative correlation between male fertility and sperm DNA damage [19]. On the other hand, our results suggest that there is no correlation between sperm DNA damage and fertility, which is supported by other studies [21-24]. The lack of correlation between DNA fragmentation and fertilization rate was shown in their overall study, but suggested that different techniques such as ICSI and IVF may have influence as to how significantly DNA damage can affect fertility rates [26, 41].

In this study flow cytometry was used to quantitatively analyze spermatozoa and the potential nuclear DNA damage induced by apoptosis. Therefore, the quality and quantity of our results are more accurate due to the use of flow cytometry compared to conventional fluorescent microscopic methods. In addition to flow cytometry, our study is innovative in virtue of sufficient technical replicates per bull and their strong fertility data. The sperm gradient isolation method provides a selection of immature spermatozoa mostly with DNA damage compared to the use of whole semen, which may cause a bias in the results. According to a recent study, semen processing by density gradient centrifugation is useful in selecting sperm with higher double-strand DNA integrity. In this study, the DNA fragmentation index [42] for whole semen (without percoll isolation) was more than $30 \%$ compared to the DFI of spermatozoa separated by $50 \%$ of a gradient solution [43]. Unlikely, in our study, since we used $45 \%$ of gradient solution, sperm with DNA fragmentation detected by TUNEL was about less than $5 \%$ of the whole cell population. According to the previous studies, $45 \%$ of gradient solution approach does not allow the sperm selection according to their viability, motility or cell integrity [32].

Since neither intrinsic nor extrinsic apoptotic pathways in sperm were the focus of our study, any speculations on the origin of DNA damage cannot be obtained. Since cryopreserved sperm is still being used for A.I. in the field, the current study focuses on only frozen sperm other than fresh semen. Cryopreservation affects sperm motility, vitality and its DNA integrity, as well as leading to increases in intracellular $\mathrm{Ca}_{2}{ }^{+}$concentration which leads to the release of pro-apoptotic factors in the cytoplasm. Therefore, nearly $50 \%$ of spermatozoa are dead after freezing and thawing, which is called the cryo-survival rate [10], and this percentage is considered common in bull sperm [33]. The apoptotic cell population was determined less than $10 \%$ in our study because only cryopreserved spermatozoa were used and $50 \%$ of the cell population was already dead prior to the detection of DNA damage induced by apoptosis. However, a number of studies have shown the implications of cryopreservation and other stress responses of animals during spermatogenesis in effecting apoptosis-like events in sperm [44-46].

In conclusion, our results showed that the most relevant fertility markers might be the percentage of necrotic spermatozoa detected by flow cytometry and live spermatozoa determined via eosin-nigrosin staining and that there is no relationship between apoptosis and male fertility. None of the apoptotic variables were determined as fertility marker in this study, so apoptotic markers may not be considered as fertility indicators. Overall, apoptosis might considerably be induced during spermatogenesis, and sperm cells rapidly undergo necrosis opposed to apoptosis following cryopreservation. Unlike apoptosis, necrosis might be the main pathway that influences sperm viability after thawing. Thus, further clinical studies should be performed to determine molecular mechanism of the intrinsic apoptotic pathways including expression and roles of apoptotic proteins. 


\section{Acknowledgements}

The funding of this study was provided by Mississippi Agricultural and Forestry Experiment Station, and by Alta Genetics, Inc.

\section{References}

1. Setchell BP, D’Occhio MJ, Hall MJ, Laurie MS, Tucker MJ, Zupp JL. Is embryonic mortality increased in normal female rats mated to subfertile males? J Reprod Fertil 1988; 82: 567-574. [Medline] [CrossRef]

2. Spanò M, Bonde JP, Hjollund HI, Kolstad HA, Cordelli E, Leter G. Sperm chromatin damage impairs human fertility. The Danish First Pregnancy Planner Study Team. Fertil Steril 2000; 73: 43-50. [Medline]

3. Vaux DL, Korsmeyer SJ. Cell death in development. Cell 1999; 96: 245-254. [Medline] [CrossRef]

4. Marchetti C, Obert G, Deffosez A, Formstecher P, Marchetti P. Study of mitochondrial membrane potential, reactive oxygen species, DNA fragmentation and cell viability by flow cytometry in human sperm. Hum Reprod 2002; 17: 1257-1265. [Medline] [CrossRef]

5. Sakkas D, Mariethoz E, Manicardi G, Bizzaro D, Bianchi PG, Bianchi U. Origin of DNA damage in ejaculated human spermatozoa. Reviews of reproduction 1999; 4: 31-37. [Medline] [CrossRef]

6. Martin G, Cagnon N, Sabido O, Sion B, Grizard G, Durand P, Levy R. Kinetics of occurrence of some features of apoptosis during the cryopreservation process of bovine spermatozoa. Hum Reprod 2007; 22: 380-388. [Medline] [CrossRef]

7. Aitken RJ, Findlay JK, Hutt KJ, Kerr JB. Apoptosis in the germ line. Reproduction 2011; 141: 139-150. [Medline] [CrossRef]

8. Reed JC. Proapoptotic multidomain Bcl-2/Bax-family proteins: mechanisms, physiological roles, and therapeutic opportunities. Cell death and differentiation 2006; 13: 1378-1386. [Medline] [CrossRef]

9. Anzar M, He L, Buhr MM, Kroetsch TG, Pauls KP. Sperm apoptosis in fresh and cryopreserved bull semen detected by flow cytometry and its relationship with fertility. Biol Reprod 2002; 66: 354-360. [Medline] [CrossRef]

10. Peña FJ, Rodriguez Martinez H, Tapia JA, Ortega Ferrusola C, Gonzalez Fernandez L, Macias Garcia B. Mitochondria in mammalian sperm physiology and pathology: a review. Reprod Domest Anim 2009; 44: 345-349. [Medline] [CrossRef]

11. Martin G, Sabido O, Durand P, Levy R. Cryopreservation induces an apoptosis-like mechanism in bull sperm. Biol Reprod 2004; 71: 28-37. [Medline] [CrossRef]

12. Sakkas D, Moffatt O, Manicardi GC, Mariethoz E, Tarozzi N, Bizzaro D. Nature of DNA damage in ejaculated human spermatozoa and the possible involvement of apoptosis. Biol Reprod 2002; 66: 1061-1067. [Medline] [CrossRef]

13. Paasch U, Grunewald S, Agarwal A, Glandera HJ. Activation pattern of caspases in human spermatozoa. Fertil Steril 2004; 81(Suppl 1): 802-809. [Medline] [CrossRef]

14. Ricci G, Perticarari S, Boscolo R, Montico M, Guaschino S, Presani G. Semen preparation methods and sperm apoptosis: swim-up versus gradient-density centrifugation technique. Fertil Steril 2009; 91: 632-638. [Medline] [CrossRef]

15. Chaveiro A, Santos P, da Silva FM. Assessment of sperm apoptosis in cryopreserved bull semen after swim-up treatment: a flow cytometric study. Reprod Domest Anim 2007; 42: 17-21. [Medline] [CrossRef]

16. Gong $\mathbf{Y}, \mathbf{W u} \mathbf{J}$, Huang $\mathbf{Y}$, Shen $\mathbf{S}$, Han X. Nonylphenol induces apoptosis in rat testicular Sertoli cells via endoplasmic reticulum stress. Toxicology letters 2009; 186: 84-95. [Medline] [CrossRef]

17. Chen WS, Xu PZ, Gottlob K, Chen ML, Sokol K, Shiyanova T, Roninson I, Weng W, Suzuki R, Tobe K, Kadowaki T, Hay N. Growth retardation and increased apoptosis in mice with homozygous disruption of the Aktl gene. Genes \& Development 2001; 15: 2203-2208. [Medline] [CrossRef]

18. Henkel R, Hajimohammad M, Stalf T, Hoogendijk C, Mehnert C, Menkveld R, Gips H, Schill WB, Kruger TF. Influence of deoxyribonucleic acid damage on fertilization and pregnancy. Fertil Steril 2004; 81: 965-972. [Medline] [CrossRef]

19. Simon L, Lutton D, McManus J, Lewis SE. Sperm DNA damage measured by the alkaline Comet assay as an independent predictor of male infertility and in vitro fertilization success. Fertil Steril 2011; 95: 652-657. [Medline] [CrossRef]

20. Waterhouse KE, Haugan T, Kommisrud E, Tverdal A, Flatberg G, Farstad W, Evenson DP, De Angelis PM. Sperm DNA damage is related to field fertility of semen from young Norwegian Red bulls. Reprod Fertil Dev 2006; 18: 781-788. [Medline] [CrossRef]

21. Colombero LT, Hariprashad JJ, Tsai MC, Rosenwaks Z, Palermo GD. Incidence of sperm aneuploidy in relation to semen characteristics and assisted reproductive outcome. Fertil Steril 1999; 72: 90-96. [Medline] [CrossRef]

22. Weng SL, Taylor SL, Morshedi M, Schuffner A, Duran EH, Beebe S, Oehninger S. Caspase activity and apoptotic markers in ejaculated human sperm. Mol Hum Reprod 2002; 8: 984-991. [Medline] [CrossRef]
23. Morris ID, Ilott S, Dixon L, Brison DR. The spectrum of DNA damage in human sperm assessed by single cell gel electrophoresis (Comet assay) and its relationship to fertilization and embryo development. Hum Reprod 2002; 17: 990-998. [Medline] [CrossRef]

24. Henkel R, Kierspel E, Hajimohammad M, Stalf T, Hoogendijk C, Mehnert C, Menkveld R, Schill WB, Kruger TF. DNA fragmentation of spermatozoa and assisted reproduction technology. Reprod Biomed Online 2003; 7: 477-484. [Medline] [CrossRef]

25. Khalili MA, Aghaie-Maybodi F, Anvari M, Talebi AR. Sperm nuclear DNA in ejaculate of fertile and infertile men: correlation with semen parameters. Urol J 2006; 3: 154-159. [Medline]

26. Bakos HW, Thompson JG, Feil D, Lane M. Sperm DNA damage is associated with assisted reproductive technology pregnancy. Int J Androl 2008; 31: 518-526. [Medline] [CrossRef]

27. Blaschek M, Kaya A, Zwald N, Memili E, Kirkpatrick BW. A whole-genome association analysis of noncompensatory fertility in Holstein bulls. J Dairy Sci 2011; 94 4695-4699. [Medline] [CrossRef]

28. Peddinti D, Nanduri B, Kaya A, Feugang JM, Burgess SC, Memili E. Comprehensive proteomic analysis of bovine spermatozoa of varying fertility rates and identification of biomarkers associated with fertility. BMC Systems Biology 2008; 2: 19. [Medline] [CrossRef]

29. Zwald NR, Weigel KA, Chang YM, Welper RD, Clay JS. Genetic selection for health traits using producer-recorded data. II. Genetic correlations, disease probabilities, and relationships with existing traits. J Dairy Sci 2004; 87: 4295-4302. [Medline] [CrossRef]

30. Zwald NR, Weigel KA, Chang YM, Welper RD, Clay JS. Genetic selection for health traits using producer-recorded data. I. Incidence rates, heritability estimates, and sire breeding values. J Dairy Sci 2004; 87: 4287-4294. [Medline] [CrossRef]

31. Chang YM, Gianola D, Heringstad B, Klemetsdal G. Effects of trait definition on genetic parameter estimates and sire evaluation for clinical mastitis with threshold models Anim Sci 2004; 79: 355-363.

32. D'Amours O, Frenette G, Fortier M, Leclerc P, Sullivan R. Proteomic comparison of detergent-extracted sperm proteins from bulls with different fertility indexes. Reproduction 2010; 139: 545-556. [Medline] [CrossRef]

33. Felipe-Perez YE, Juarez ML, Hernandez EO, Valencia JJ. Viability of fresh and frozen bull sperm compared by two staining techniques. Acta Veterinaria Brasilica 2008; 2 123-130.

34. Dott HM, Foster GC. A technique for studying the morphology of mammalian spermatozoa which are eosinophilic in a differential 'life-dead' stain. J Reprod Fertil 1972; 29 443-445. [Medline] [CrossRef]

35. Laemmli UK. Cleavage of structural proteins during the assembly of the head of bacteriophage T4. Nature 1970; 227: 680-685. [Medline] [CrossRef]

36. Oltvai ZN, Korsmeyer SJ. Checkpoints of dueling dimers foil death wishes. Cell 1994; 79: 189-192. [Medline] [CrossRef]

37. Knudson CM, Tung KS, Tourtellotte WG, Brown GA, Korsmeyer SJ. Bax-deficient mice with lymphoid hyperplasia and male germ cell death. Science 1995; 270: 96-99. [Medline] [CrossRef]

38. Zhang ZH, Zhou XC, Wei P, Hu ZY, Liu YX. Expression of Bcl-2 and Bax in rhesus monkey testis during germ cell apoptosis induced by testosterone undecanoate. Archives of Andrology 2003; 49: 439-447. [Medline] [CrossRef]

39. Woolveridge I, Bryden AA, Taylor MF, George NJ, Wu FC, Morris ID. Apoptosis and expression of apoptotic regulators in the human testis following short- and long-term anti-androgen treatment. Mol Hum Reprod 1998; 4: 701-707. [Medline] [CrossRef]

40. Hendricks KE, Hansen PJ. Can programmed cell death be induced in post-ejaculatory bull and stallion spermatozoa? Theriogenology 2009; 71: 1138-1146. [Medline] [CrossRef]

41. Benchaib M, Braun V, Lornage J, Hadj S, Salle B, Lejeune H, Guerin JF. Sperm DNA fragmentation decreases the pregnancy rate in an assisted reproductive technique. Hum Reprod 2003; 18: 1023-1028. [Medline] [CrossRef]

42. Zhuang Z, Ezzat SZ, Vortmeyer AO, Weil R, Oldfield EH, Park WS, Pack S, Huang S, Agarwal SK, Guru SC, Manickam P, Debelenko LV. Kester MB, Olufemi S-E, Heppner C Crabtree JS, Burns AL, Splegel AM, Marx SJ, Chandrasekharappa SC, Collins FS, Emmert-Buck MR, Llotta LA, Asa SL, Lubensky IA. Mutations of the MEN1 tumor suppressor gene in pituitary tumors. Cancer Res 1997; 57: 5446-5451. [Medline]

43. Brahem S, Mehdi M, Elghezal H, Saad A. Semen processing by density gradient centrifugation is useful in selecting sperm with higher double-strand DNA integrity. Andrologic 2011; 43: 196-202. [Medline] [CrossRef]

44. Khan DR, Ahmad N, Anzar M, Channa AA. Apoptosis in fresh and cryopreserved buffalo sperm. Theriogenology 2009; 71: 872-876. [Medline] [CrossRef]

45. Nur Z, Zik B, Ustuner B, Sagirkaya H, Ozguden CG. Effects of different cryoprotective agents on ram sperm morphology and DNA integrity. Theriogenology 2010; 73 : 1267-1275. [Medline] [CrossRef]

46. Said TM, Gaglani A, Agarwal A. Implication of apoptosis in sperm cryoinjury. Reprod Biomed Online 2010; 21: 456-462. [Medline] [CrossRef] 